\title{
Global Television and Cultural Promotion: Taming the Cultural Dilemma among Nigerian Youths
}

\author{
Stanislaus Iyorza
}

\begin{abstract}
This paper sets out to re-examine the impact of global television on the behavior of youths in Nigeria. The paper identifies cultural imperialism as the most significant impact of global television achieved through programs like sports, drama, musicals, and violent movies transmitted to Nigeria and other third world nations. These programs are transmitted under the guise of informative, educational and entertainment programs while the Nigerian youths are the most affected victims. Through careful analysis of previous researches and literatures, this paper posits that Nigerian youths are caught between the dilemma of the foreign cultures and their indigenous cultures in terms of dress codes, speech, dance and the general ideologies. This paper concludes that aggressive cultural communication and government's programs targeted at youths at all levels are one of the suggestions that can help tame the cultural dilemma among the youth.
\end{abstract}

Index Terms - Cultural dilemma, cultural promotion, global television, Nigerian youth.

\section{INTRODUCTION}

Nigerian youths are the most vulnerable victims of cultural imperialism. Most of them can no longer speak the Nigerian local languages, dress in Nigerian traditional attires, sing Nigerian local songs, eat Nigerian local food nor abide by the Nigerian cultural values. They prefer to speak Queen's English. Even those who are born and bred in the city in the average Nigerian homes can neither speak Queen's English nor their local dialect. They are masters in speaking 'Pidgin English' which is an adulterated version of English language. They also prefer western attires like suit, jackets and trendy wears patterned after the values of western cultures. Even though some weather conditions warrant these wears, the habitual inclination to western lifestyles at the expense of the Nigerian traditional lifestyles amounts to cultural adoption by the Nigerian youths. These youths master hip hop songs as sung by western musicians. The young Nigerian ladies are exceptionally used to patronizing fast food owned mostly by international food vendors like UAC Foods.

Nigerian youths are increasingly adopting wholesale cultural values that are alien and not compatible with the Nigerian way of life [1]. The Nigerian youth may not be totally responsible for lack of appreciation of our culture. Famous among vehicles of cultural imperialism are the mass media. Television, with its visual, audio and motion capacities ranks among the most influential medium of

Manuscript received August 20, 2013; revised October 23, 2013.

Stanislaus Iyorza is with the Department of Theatre and Media Studies, University of Calabar, Nigeria, West Africa (e-mail: stamorji@yahoo.com). communication in recent times. Television programs are transmitted at the local level to the local audience, national level to the national audience who cut across different ethnic groups and religion, and global level to the international community or audience who are situated within different countries of different continents. Global television, which includes satellite transmission of programs from one country to many other countries, is the most vibrant instrument of cultural imperialism.

Global television transmits programs with one or two of the following three characteristics namely: information, education and entertainment. New categories of programs include edutainment and infotainment. These are postmodern coinages that involve education, entertainment, and information qualities in a piece of media programs. Famous among the programs under these categories include news, drama, adverts, musicals and sports. On global television, these programs are transmitted mostly from western countries in Europe including Germany, England, Italy and United States of America, and also recently from Asian countries like Japan and China. The overall impact of foreign or global television program on Nigerian youths is a significant switch from local to foreign cultures and adoption of global life styles.

The Nigerian government has made tremendous efforts towards the promotion of indigenization in all sectors of the economy including the promotion of indigenous television and radio program and production of indigenous consumer programs for her citizens. The aim of the Nigerian government towards her indigenization policy has been to encourage the Nigerian youths who are already caught in the dilemma of embracing the local cultures and holding firm unto adopted foreign cultures. The thrust of this paper is to explore the Nigerian youths' reaction to foreign television programs, the impact of such programs on their lifestyles, and the possibility of making the Nigerian local content more attractive to the Nigerian youth.

\section{Global Television Programmes AND CUltural PROMOTION}

Television, radio, newspaper and other mass media channels of communication are the most influential agents of socialization between the developed and the developing nations [2]. However, television has structural characteristics of visual images, motion and audio capacities that are creatively combined with the specific context of the transmitted messages by means of electromagnetic waves. In Nigeria, $60 \%$ of the population of more than 160 million including youths is reached through television broadcast with both positive and negative impacts [3]. 
These television broadcasts include global television transmission which is geometrically increasing on daily basis. Global television refers to international channels of communication that transmit sound, images and motion simultaneously to countries across the globe. Global television programs are transmitted through satellite or the internet and the audiences at the receiving end access the programs through various forms of subscription - using receptive apparatus like the television monitors, computer monitors and mobile phones.

As a global medium, global television transmits programs beyond national boundaries and this is done by different countries with the aim of serving their people settled in other countries and also to propagate the policies of the respective countries [4]. Some famous channels of global television in Nigeria include British Broadcasting Corporation (BBC), Cable News Network (CNN), and Channel O. Others include E-Entertainment, Science Fiction and Super Sport channels. All these channels transmit programs with news, drama, sports, musical or advertisement element or a combination of two or more.

The impact of global television on viewers is significantly strong due to the channels' ability to use sound, visual and motion as a means of transmitting new developments, new entertainment activities and knowledge enriching programs from developed countries where the messages are generated and transmitted. Thus, global television allows a lot of creativity, variety and flexibility through a combination of sight, sound, motion, color, drama and persuasiveness. Television has tremendous dramatic capacity to turn ordinary products into something important, exciting and interesting and helps in creating a positive association [5]. Global television is therefore used as a medium for influencing the views, beliefs norms and practices of other people especially the youths.

Cultural promotion is therefore a major feature of global television whether primarily intended or not. Cultural promotion is a marriage of two key words: 'Culture' and 'Promotion.' Culture is the social heritage of a society which includes all the knowledge, beliefs, customs and skills as well as other materials and non-material artifacts and behavior of members [6]. 'Promotion' in the context of media and communication is the coordination of all sellerinitiated efforts to set up channels of information and persuasion to sell goods and services or promote an idea [7].

Global television promotes cultures both deliberately and pretentiously. Through educational programs for children like 'Barney and Friends' and 'Sesame Street' from the United States of America, and the transmission of movies and international television soaps and drama series from India, China, Europe and Southern and Northern America, the lifestyles in these countries are embedded in the acts, speech and general behavior of actors and transmitted to the audiences in less developed countries that lack the media machinery to transmit global messages like their developed counterparts. These programs are deliberately packaged and conscious efforts are put in place to transmit them. However, global adverts about goods, services and locations for tourism from some developed countries are pretentiously transmitted amidst programs like news, sports and other educational programs.
Certainly, global televisions are justified agents of cultural promotions. Those at the receiving end are poor developing countries in Africa including Nigeria. The most affected audience is the youth. Statistics show that the youths are the most exposed to television programs including those from foreign countries the impact of these global television programs in terms of cultural promotion can better be imagined.

\section{IMPACT OF CULTURAL PROMOTIONS ON NIGERIAN YOUTHS}

Cultural promotions through global television have enormous impact on the Nigerian youth today. Cultural promotions are made possible by a set of cosmopolitan culture considered to be elite and popular, scientific and artistic and linked through the medium of English as a universal rather than a national language [8]. In the process, western dances have taken over African traditional dances among the youths in public places. Foreign meals including fried rice, vegetable salads, baked snacks and can foods have become more preferred to African delicacies such as 'abacha' and 'Ugba' (meal made of cassava and vegetables and other condiments) and fried beans cake known in local parlance as 'akara'. Language as a means of communication, styles of houses and even schools have assumed similar posture with what is available in the western world.

Cultural promotions actually influence the taste, lives and aspirations of virtually every nation and in some way; they are viewed as corrupting and antagonistic to subcultures of the third world countries [9]. The promotion of cultures through global television programs like drama, dance, music and advertising negatively affects viewers. Violent and aggressive behavior depicted on the television screen consumes children and affect teenagers. The trend is on the increase with a great leap in communication technological development where they receive great amount of information regarding new fashion and fad and other products [10]. With the opportunity provided by the new media, Nigerian youths today spend more time watching global television programs such as musicals which are corrupted with nudity and suggestive dance steps, drama series with strong story lines of love, action movies featuring gangsters, acts of shooting, and killings, including modes of dressing, speaking and killing as well as modes of walking which are unacceptable in the context of African culture.

Consequently, the demeanor of dressing in female and male teens is one of the impacts of global television viewing. Teenage girls flaunt around their bosoms with rumps hanging out of their clothing. Teenage males strut around their pant sagging below their derriere, wearing many chains around their necks trying to resemble a rap artiste. Global television viewing obviously makes youth to believe that what they watch is the trend. The young males are made to feel the illusion that having this particular image will bring them women galore.

Also, most Nigerian youths are affected by the accent and language of the pop stars, actors and actresses and the characters in the advert the watch on the global television [11]. Girls are accepting being called "bitch" (a female dog) 
by the same opposite sex because they see musical television from the foreign countries with women shaking and groaning while being called 'bitch'. The youth copy suggestive dance steps, nude modes of dressing, and images that incite young men and women. Most youths copy violent behavior from what they view on global television. They learn how to be unnecessarily aggressive. The Nigerian youths express all sorts of love behavior in public which is un-African. In addition they prefer to watch the European league to the detriment of their own local league. No more "tales by moonlight" as parents also retire early to bed after a hard day's job. Nigerian ladies prefer foreign creams, soaps and cosmetics to the local counterparts. Parents allow children to watch most corrupt global television programs without any guidance.

Global television has remained the key agent of cultural promotion. The cultures in question are the beliefs, norms, behavior of people from developed countries of Asia, America and Europe. The cultures are highlighted, featured and transmitted as valuable and relevant to human existence. The transmission is made possible through global television programs such as drama series, adverts, news, musical, educational packages, science fiction and sports. This implies that the programs transmitted to third world countries including Nigeria, from Asia, America and Europe primarily have the purpose of information, education and entertainment of the continent's people and the citizens of the countries. However, the impact of the information behind each program is unquestionably imperial. The most vulnerable audience of global television programs are the youths.

In Nigeria, the youths are young persons of between childhood age and the period before adulthood. They are the majority dependants on their parents for food, clothing and shelter. They are the most idle and unemployed persons who depend on any available information to satisfy their insatiable quest for knowledge that would prepare them for life in future. They depend on local and global media especially television and the internet because of their features of visual, audio, motion and easy accessibility. Their continuous patronage of global television programs have robbed majority of the Nigerian youths of the Nigerian culture. The Nigerian youths have adopted foreign cultures in forms of manners of speaking, dressing, acting, behaving, eating, loving, thinking, dancing, singing and more. The list is endless.

To tame this, the local television stations should increase the hours for transmitting knowledge-driven programs on Nigerian cultures. The programs should be participatory, competitive and rewarding. The Nigerian Broadcasting Corporation (NBC) should ban global television programs with corrupt contents of nudity and violence without discouraging entertainment programs like foreign sports. Drama series and adverts that possess corrupt tendencies and pose a threat to the Nigerian cultures should be banned from the Nigerian airwaves.

Finally, the Federal Government of Nigeria should be involved in youth development agenda through the agents of socialization. The Federal Government of Nigeria should involve families in workshops and knowledge-enriching seminars on culture. The schools (secondary and tertiary) should encourage the organization of cultural days. Most tertiary institutions in Nigeria are doing this already, but the activities should be sustained. At the community levels, writing and speaking competitions should be organized in local dialects among the youths including fashion parades. Local meals should be prepared at such events which should be held more frequently. The Nigerian youths need to embrace his culture even in the wake of intensified foreign cultural promotion by global television.

\section{REFERENCES}

[1] L. Otufodurin. (2011). Cultural Dilemmma. [Online]. Available: http://www.thenationonline.net.

[2] E. Nwagbara, Sociology of Mass Communication, Calabar: ElSapphire LTD, 2006.

[3] S. Iyorza, "Globalization, television and the dress culture of Nigerian university ladies," paper presented at Ph.D. Seminar in Calabar, Cross River State, Nigeria in August 2007.

[4] S. Hasan, Mass Communication: Principles and Concepts, New Delhi: CBS Publishers. 2013.

[5] S. Hasan, Mass Communication: Principles and Concept, pp. 536.

[6] E. Edet and S. Iyorza, "Global media and cultural domination: strategies for a new world information and communication order for Africa," Journal of Globalization, Makurdi: Aboki Publishers, vol. 2, no. 1, pp. 19-24, June 2008.

[7] G. Belch and M. Belch, Advertising and Promotion: An Integrated Marketing Communications Perspective, New York: McGraw-Hill. 2001.

[8] P. Hirst and G. Thompson, Globalization in Question, Cambridge: Polity, 1999.

[9] D. Rothkopt, "In precise of cultural imperialism," Globalization and the Challenges of a New Century, Eds Partricia O' Meara, Hans Mechhlinger, Manix Krain. Bloomington: Indiana. 2000.

[10] E. Nwagbara, Sociology of Mass Communication, Calabar: ElSapphire LTD, 2006.

[11] D. Lopez. (December 27, 2012). Do watching and listening to music videos have a negative effect on teens? [Online]. Available: http://www/worldmusic.net.

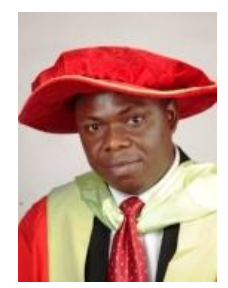

Stanislaus Iyorza was born at Mkar, Gboko in Benue State of Nigeria on the $27^{\text {th }}$ day of February 1977 , attended and obtained his First School Leaving Certificate (FSLC) in 1987 from Kusaki Nursery/Primary School, Gboko, Benue State of Nigeria, West Africa. He attended Mount Saint Gabriel Secondary School between 1988 and 1993 and obtained a Senior Secondary School Certificate (SSCE) in the Arts in 1993 then proceeded to Benue State University, Makurdi in Benue State where he earned a Bachelor of Arts Degree in Mass Communication in April 2000. He also attended the University of Calabar, Cross River State of Nigeria and earned a Master of Arts Degree in Theatre Arts in October 2005 and a Doctor of Philosophy (Ph.D) in Theatre and Media Studies in August 2010. His major field of study is Media Advertising and Speech Communication. He has worked as an Editor in the Information and Public Relations Department of the University of Calabar between September 2000 and July 2006 and proceeded to the Faculty of Arts, as an Assistant Lecturer where he rose to the rank of Lecturer 1 in the Department of Theatre and Media Studies from July 2006 to date. He has book publications such as 'Mass Media and Communication Techniques' published in Calabar, Cross River State by the University of Calabar Press in 2008 and 'An Oral English Course: Introductory Guide to Speech Arts' in Calabar Cross River State by Maesot and Company in 2012. His research interest has been in the role of communication in behavior change among different audience in different locations concerning diverse fields. Dr Iyorza is an Associate Member of Nigerian Institute of Public Relations (ANIPR) and National Association of Educational and Media Technologists (NAEMT) in Nigeria. 